\title{
Proapoptotic and Antiangiogenic Activities of Arctium Lappa L. on Breast Cancer Cell Lines
}

\author{
Mohamad Taleb Agha $\mathbb{D}^{1},{ }^{1}$ Hussein M. Baharetha, ${ }^{1,2}$ Majed Ahmed Al-Mansoub, \\ Yasser M. Tabana, ${ }^{1,3}$ Nur Hidayah Kaz Abdul Aziz, ${ }^{1}$ Mun Fei Yam $\mathbb{D D}^{1}$ \\ and Amin Malik Shah Abdul Majid $\mathbb{D}^{1,4}$ \\ ${ }^{1}$ EMAN Testing \& Research Laboratory, Department of Pharmacology, School of Pharmaceutical Sciences, \\ Universiti Sains Malaysia, Minden 11800, Pinang, Malaysia \\ ${ }^{2}$ Department of Pharmacy, College of Medicine and Health Sciences, Hadhramout University, Al Mukalla, Hadhramout, Yemen \\ ${ }^{3}$ Faculty of Pharmacy and Pharmaceutical Sciences, University of Alberta, Edmonton, Alberta, Canada \\ ${ }^{4}$ ACRF Department of Cancer Biology and Therapeutics, The John Curtin School of Medical Research, \\ Australian National University, Canberra, Australia \\ Correspondence should be addressed to Amin Malik Shah Abdul Majid; aminmalikshah@gmail.com
}

Received 18 September 2019; Revised 16 March 2020; Accepted 23 April 2020; Published 19 May 2020

Academic Editor: Umit Tursen

Copyright (C) 2020 Mohamad Taleb Agha et al. This is an open access article distributed under the Creative Commons Attribution License, which permits unrestricted use, distribution, and reproduction in any medium, provided the original work is properly cited.

\begin{abstract}
In this study, the bioactivity-guided fractionation was conducted on the aerial parts of Arctium lappa L. and then the extracts were tested in vitro on breast cancer (MCF-7), colorectal cancer (HCT-116), and normal cells (EA.hy926). The n-hexane fraction (EHX)

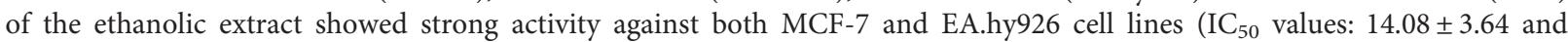
$27.25 \pm 3.45 \mu \mathrm{g} / \mathrm{mL}$, respectively). The proapoptotic activity of EHX was assessed using MCF-7. Morphological alterations were visualized using Hoechst staining and a transmission electron microscope. Cancer cell signal transduction pathways were investigated, and EHX significantly upregulated p53, TGF- $\beta$, and NF- $\kappa$ B. Furthermore, EHX was found to disrupt the metastatic cascade of breast cancer cells by the inhibition of cell proliferation, migration, invasion, and colonization. The antiangiogenic activity of EHX fraction showed potent inhibition of rat aorta microvessels with $\mathrm{IC}_{50}$ value: $4.34 \pm 1.64 \mu \mathrm{g} / \mathrm{mL}$. This result was supported by the downregulation of VEGF-A expression up to 54\%. Over 20 compounds were identified in EHX using GC-MS, of which stigmasterol, $\beta$-sitosterol, and 3-O-acetyllupeol are the major active compounds. Phytochemical analysis of EHX showed higher phenolic and flavonoid contents with a substantial antioxidant activity. In conclusion, this work demonstrated that $A$. lappa has valuable anticancer activity and antiangiogenic properties that might be useful in breast cancer therapy.
\end{abstract}

\section{Introduction}

Arctium Lappa L. (A. lappa) is an edible plant and it is indigenous to North Asia and Europe. It is popular as a vegetable in Asian countries and it was used in many traditional European dishes. In China, it is used as a medicinal plant $[1,2]$. The anticancer characteristics of A. lappa have been validated for extracts and isolated principles through various studies. Recent studies have found that A. lappa possesses a potent antiproliferative effect against various kinds of cancer cells such as human multiple myeloma
(MM) [3], human bone marrow (k562) [4], breast (MCF-7), liver (Huh-7), oropharyngeal (HTB-43), and bladder (ECV304) [5]. The major active ingredients of $A$. lappa are lignans, sterols, terpenoids, and polyphenols. Several studies revealed that $\beta$-sitosterol (sterols) inhibited tumor growth and stimulated apoptosis in prostate cancer; in addition, it reduced the growth and metastasis in breast cancer cells [6]. Terpenoids, such as lupeol, are reported as a potent antiangiogenic drug. The lupeol is able to suppress the neovessel formation in nontumor models, such as CAM and rat cornea model, and in a xenograft tumor model. It also downregulates angiogenic 
genes such as MMP-2 and -9, VEGF-A, flt-1, and HIF-1 $\alpha$ which are associated with tumorigenic conditions $[7,8]$.

Breast cancer is the most common cancer among women. In 2019, an estimated 268,600 women were diagnosed with breast cancer in the United States. Approximately $12.8 \%$ of American women will be diagnosed with breast cancer over their lifetime [9, 10]. Breast cancer is classified into three major subtypes based on the expression of the molecular markers such as estrogen receptor (ER), progesterone receptor (PR), and human epidermal growth factor receptor 2 (HER2). Hormone receptor-positive is the most commonly diagnosed of all breast cancer $(70 \%$ of patients). The triple-negative breast cancer is more aggressive than the other subtypes and more likely to recur $[10,11]$. Apoptosis and angiogenesis events are firmly controlled by complex molecular signaling systems [12]. Bcl2 gene is found to be overexpressed in $70 \%$ of breast cancer cells, and it is linked to p53 gene downregulation. p53 has been referred to as "Guardian of the Genome" due to cell cycle arrest and apoptosis induction effect [13-15]. A TGF- $\beta$ signaling pathway is identified as a double-edged sword, which can function as a tumor suppressor and oncogenic pathway. The overexpression of TGF- $\beta$ in breast cancer cells is able to suppress tumor development markedly [16]. NF- $\kappa \mathrm{B}$ is an essential contributor to angiogenesis and cell death suppression. Nevertheless, several studies reported that NF$\kappa \mathrm{B}$ activation impedes tumorigenesis in in vivo tumor models [17]. VEGF-A is a pivotal factor for the angiogenesis cascade. It regulates the neovascularization of several pathological impairments and diseases such as breast cancer [18].

In this work, the aerial parts of A. lappa were subjected to bioactivity-guided fractionation and the extract from n-hexane was tested in vitro and ex vivo for its proapoptotic activity and antiangiogenic properties.

\section{Materials and Methods}

2.1. Chemicals and Materials. The solvents used acetone, ethanol, ethyl acetate, petroleum ether, n-butanol, and n-hexane were produced by Riedel-de Haën, Germany. The chemicals used in the cell culture study, that is, Dulbecco's modified Eagle medium, heat-inactivated fetal bovine serum, penicillin/streptomycin solution, Roswell park memorial institute medium, phosphate-buffered saline, trypsin, tetrazolium salt (3-(4,5-dimethylthiazol-2-yl)-2,5diphenyl tetrazolium bromide), and dimethyl sulfoxide, were produced by Sigma-Aldrich, Germany. Human breast cancer cells (MCF-7), colorectal cancer cells (HCT-116), and endothelial cells (EA.hy926) were purchased from American Type Culture Collection (ATCC, Manassas, VA, USA). The reagents for the ex vivo culture study (amphotericin $\mathrm{B}$, aprotinin, fibrinogen, Earle's salt (M199), L-glutamine, gentamycin, thrombin, matrigel, and suramin) and Hoechst assay (Hoechst 33342 stain and para-formaldehyde) were purchased from Sigma-Aldrich, USA.

2.2. Plant Collection and Authentication. The aerial part of $A$. lappa was collected from the garden of medicinal plants of
Damascus University, Damascus, Syria, in March 2015. A voucher specimen was authenticated by a botanist $\mathrm{Mr}$. Shunmugam (code: 11328) and deposited at the Herbarium unit of the School of Biology, Universiti Sains Malaysia.

2.3. Extraction and Fractionation. The bioassay-guided crude extract of $A$. lappa was prepared by maceration method at $45^{\circ} \mathrm{C}$ for $48 \mathrm{~h}$. Sequentially, three different solvents with different polarities were used starting with nonpolar solvent petroleum ether (PT), followed by the ethanol (ETH), and water (WT) [19]. The three extracts were then tested for MTT assay and the ETH extract showed the highest activity. The bioassay-guided fractionation was carried out by liquid-liquid separation and four solvents were used, that is, n-hexane (EHX), ethyl acetate (EEA), n-butanol (EB), and water (EW), respectively [20].

2.4. Cell Culture and Cell Lines. Human cell lines, HCT 116 (colorectal carcinoma), MCF-7 (hormone-sensitive breast cancer), and EA.hy926 (human endothelial cell), were obtained from ATCC, USA. Cells were cultured at a humidified atmosphere $\left(37^{\circ} \mathrm{C}\right)$ with $\mathrm{CO}_{2}(5 \%)$ in a growth medium supplemented with $10 \% \mathrm{FBS}$ and penicillin/streptomycin (1\%). MCF-7 and EA.hy926 cells were cultured in DMEM (Gibco/Life technology, UK), while HCT-116 cells were cultured in RPMI-1640 (Sigma-Aldrich, USA).

2.5. Cell Viability. MTT assay was performed to assess the antiproliferative effect of $A$. lappa extracts and fractions on HCT-116, MCF-7, and EA.hy926 cells. The assay plates were read using a microtiter plate reader (Thermolab Systems, Finland) at $570 \mathrm{~nm}$. Absolute ethanol was used as a negative control. Tamoxifen and betulinic acid were used as a positive control for MCF-7 and EA.hy926, respectively [21, 22].

2.6. Hoechst Stain Test. Nuclear chromatin condensation is a critical feature characterizing apoptosis. MCF-7 at a concentration of $1 \times 10^{5}$ cells $/ \mathrm{mL}$ per well was added to 24 -well plate, and it was incubated for $24 \mathrm{~h}$. The old medium was replaced and EHX was added at a concentration of 7.5, 15, and $30 \mu \mathrm{g} / \mathrm{mL}$ or absolute ethanol for the control sample. The plate was reincubated for another $24 \mathrm{~h}$. The medium was discarded, cells were rinsed by PBS, and para-formaldehyde $4 \%(\mathrm{w} / \mathrm{v}$ ) was added for cell fixation. After $20 \mathrm{~min}$, Hoechst 33258 stain $(10 \mu \mathrm{g} / \mathrm{mL}$; Sigma $)$ was added to each well $(300 \mu \mathrm{L} /$ well), and the plate was incubated for a further $20 \mathrm{~min}$. Microimages were snapped under 20x magnification using a fluorescence microscope (EVOS fl, USA) [23].

2.7. Morphological Changes in MCF-7 by Using a Transmission Electron Microscope (TEM). MCF-7 cells were treated for $24 \mathrm{~h}$ with EHX or absolute ethanol. Cells were fixed with 0.1 M McDowell-Trump and stained with osmium tetroxide (1\%). The cells were then solidified in agar (2\%), cut into small slides, and dehydrated in ethanol followed by acetone. The slides were embedded in resin and infiltrated for five 
days in Suprr's mixture at $60^{\circ} \mathrm{C}$ and changed repeatedly every day. Subsequently, the strips were molded in resin molds and sliced into $0.1 \mu \mathrm{m}$ thickness. The ultrathin sections were stained with toluidine blue (Sigma-Aldrich, USA) and collected in copper grids. Consequently, it was doubly stained with uranyl acetate and lead citrate (Sigma-Aldrich, USA) [24]. Finally, the cells were photographed using TEM (EFTEM Libra 120, Carl-Zeiss, Germany) at 1250x magnification.

2.8. Cell Signal Pathways. MCF-7 cells were harvested at $50 \%-80 \%$ confluency. Cells were seeded $(75 \mu \mathrm{L} /$ well $)$ in a $96-$ well plate kit (Promega, USA) and incubated for $12 \mathrm{~h}$. The old medium was aspirated and replaced with DMEM $(75 \mu \mathrm{l})$ containing EHX $(10 \mu \mathrm{g} / \mathrm{mL})$ or the vehicle. The plate was incubated for $24 \mathrm{~h}$. Then, each well received Dual-Glo ${ }^{\circledR}$ reagent $(75 \mu \mathrm{L})$, and the plate was incubated at room temperature for $1 \mathrm{~h}$. Firefly luciferase reporter was measured by using a luminescence microplate reader (HIDEX, Finland). Dual-Glo ${ }^{\circledR}$ Stop and $\mathrm{Glo}^{\circledR}$ reagent was added to each well $(75 \mu \mathrm{L})$, and the plate was incubated at room temperature for $1 \mathrm{~h}$. Renilla luciferase reporter was measured by using a luminescence microplate reader (HIDEX, Finland). The fold change in each pathway activity was measured according to the following formula:

Fold change in pathway activity $=$ treated well ratio (Firefly/Renilla)/untreated well ratio (Firefly/Renilla).

2.9. Colony Formation Assay on MCF-7 Cell Line. The aim of this assay was to test the capability of extract to inhibit the cancer cell colonization $[25,26]$. MCF-7 was seeded $(2 \mathrm{~mL} /$ well) in a 6-well plate at a concentration of 500 cells $/ \mathrm{mL}$ and incubated for $12 \mathrm{~h}$. Old DMEM was replaced, and EHX was added at different concentrations $(0.87-7 \mu \mathrm{g} / \mathrm{mL})$; tamoxifen was used as a positive control $(10 \mu \mathrm{g} / \mathrm{mL})$, and absolute ethanol was used for negative control. After $48 \mathrm{~h}$, the treatment was replenished by fresh DMEM every 3-4 days until the formation of large colonies ( 50 cells). The colonies were fixed and stained with crystal violet $(0.2 \%)$ (SigmaAldrich, USA). The percentage of plating efficiency (PE\%) and the percentage of surviving fraction were calculated.

2.10. Cell Invasion Assay of MCF-7 Cells. The invasion assay was performed to evaluate the ability to suppress transmigration of cancer cells in the metastasis stage. Matrigel was pipetted (1:1 DMEM) in 96-well plate and incubated for $45 \mathrm{~min}$. Then, MCF-7 $(150 \mu \mathrm{L} /$ well $)$ was seeded at a concentration of 5000 cells/well. The plate was treated by EHX ( 7.5 and $15 \mu \mathrm{g} / \mathrm{mL}$ ) or absolute ethanol. After $24 \mathrm{~h}$, images were captured for each well using a florescent microscope at $4 \mathrm{x}$ magnification.

2.11. Cell Migration Assay on MCF-7 Cells. The assay was conducted to evaluate the ability to stop cells from migration [27]. A confluent monolayer of MCF-7 was scratched in a 6well plate. The plate was then treated by EHX at different concentrations (15 and $30 \mu \mathrm{g} / \mathrm{mL}$ ) or absolute ethanol.
Subsequently, images were captured at 3 time points $(0,6$, and $12 \mathrm{~h}$ ). Finally, the pictures were analyzed using Image ${ }^{\circledR}$ software at various points to measure the distance between the cells of both sides of the rip.

2.12. Experimental Animals. Sprague-Dawley male rats were provided by The Animal Research and Service Centre (ARASC) at Universiti Sains Malaysia. The animals were eight to twelve weeks old (200-230 g) and kept in transit in a quiet and clean room with suitable temperature, lighting system, and ventilation for few days before being sacrificed. The study protocol was approved by the Animal Ethics Committee, USM (approval reference number: 2016/(102) (782)).

2.13. Ex Vivo Rat Aortic Ring Assay. The three-dimensional (3D) assay was performed to estimate the antiangiogenic efficacy of compounds regarding the outgrowth sprouted of microvessels from the rat aortic ring model $[28,29]$. Thoracic aortas were carefully excised and sectioned into rings of $1 \mathrm{~mm}$ thickness in the M199 medium (Gibco/Life technology, UK). Fresh rings were explanted directly in a 48-well plate and the lower layer was added $(300 \mu \mathrm{L} /$ well $)$. Each well received $10 \mu \mathrm{L}$ of thrombin ( $50 \mathrm{U} / \mathrm{mL}$ in normal saline) (Sigma-Aldrich, USA). The plate was incubated for $60 \mathrm{~min}$, and then, the upper layer with treatment was added $(300 \mu \mathrm{L} /$ well). The plate was incubated for four days. Later on, the upper layer was pipetted out carefully and replaced with a freshly prepared upper layer with similar treatments and the plate was incubated for another $24 \mathrm{~h}$. Finally, the rings were photographed with $4 \mathrm{x}$ magnification using a microscope EVOS fl (digital inverted microscope, USA). The lower layer was composed of M199, fibrinogen $3 \mathrm{mg} / \mathrm{mL}$, aprotinin $5 \mu \mathrm{g} /$ $\mathrm{mL}$, and L-glutamine $1 \%(\mathrm{v} / \mathrm{v})$. The upper layer was composed of M199, FBS 20\% (v/v), L-glutamine $1 \%(\mathrm{v} / \mathrm{v})$, amphotericin B $1 \%(\mathrm{v} / \mathrm{v}), \varepsilon$-aminocaproic acid $0.1 \%(\mathrm{w} / \mathrm{v})$, and gentamycin $0.6 \%(\mathrm{v} / \mathrm{v})$. The treatment was prepared in various concentrations $(3-100 \mu \mathrm{g} / \mathrm{mL})$ of $A$. lappa for the calculation of $\mathrm{IC}_{50}$. Suramin $(100 \mu \mathrm{L} / \mathrm{mL})$ and absolute ethanol were used as a positive control and a negative control, respectively.

2.14. VEGF. The treated MCF-7 cells were harvested and lysed by using Wizard ${ }^{\circledR}$ SV lysis buffer (Promega, Madison, USA). The assay was run by using the ELISA kit of human VEGF-165 according to the manufacturers' protocol (Raybio, USA).

2.15. Gas Chromatography-Mass Spectrometry (GC-MS). ETH and EHX were carried out on a gas chromatograph HP $6890 \mathrm{~N}$ (G1530N) (HP, China) attached with HP 5973 (G2579A) quadrupole mass spectrometer, at $70 \mathrm{eV}$. The stationary phase was packaged in a nonpolar capillary column HP-5MS 19091S-433. The initial temperature started at $70^{\circ} \mathrm{C}$, for $2 \mathrm{~min}$. Then, it was raised to $285^{\circ} \mathrm{C}$ at a rate of $20^{\circ} \mathrm{C} / \mathrm{min}$. The helium flow rate was $1.2 \mathrm{~mL} / \mathrm{min}$. The scan time and mass range were $1 \mathrm{~s}$ and $35-650^{\circ}(\mathrm{m} / z)$, 
respectively. Then, samples were injected $(1 \mu \mathrm{L})$ at the source temperature of $230^{\circ} \mathrm{C}$ while the temperature of the quadrupole column was $150^{\circ} \mathrm{C}$. Then, mass spectra and mass/ charge ratio $(\mathrm{m} / \mathrm{z})$ of molecular ions were compared to the referenced data of the NIST02 library [30].

2.16. Measurement of Total Phenol Content. The total phenol content of ETH and EHX was evaluated using Folin-Ciocalteu reagent as performed previously $[31,32]$. The samples were prepared $(1 \mathrm{mg} / \mathrm{mL})$ of $100 \mu \mathrm{L}$ and mixed with $750 \mu \mathrm{L}$ of diluted Folin-Ciocalteu reagent in distilled water $(1: 10)$ and then incubated in the dark for $5 \mathrm{~min}$ at room temperature. Sodium bicarbonate solution $(750 \mu \mathrm{L})$ was added at a concentration of $60 \mathrm{~g} / \mathrm{L}$. Then, it was kept for $30 \mathrm{~min}$ in a dark environment at $30^{\circ} \mathrm{C}$, and the absorbance was measured at $725 \mathrm{~nm}$ using a UV spectrophotometer (Perkin Lambda 45). The gallic acid was used as a standard.

2.17. Determination of Total Flavonoid Content. Total flavonoid content was evaluated using aluminum chloride method and quercetin was used as standard [33]. The samples (500 $\mu \mathrm{L}$ in tubes) were prepared in a concentration of $1 \mathrm{mg} / \mathrm{mL}$; then, we added $0.1 \mathrm{~mL}$ of $10 \%$ aluminum chloride solution, $1.5 \mathrm{~mL}$ of methanol, $0.1 \mathrm{~mL}$ of $1 \mathrm{M}$ potassium acetate solution, and $2.8 \mathrm{~mL}$ of distilled water. After incubation for $30 \mathrm{~min}$ at room temperature, the absorbance reading was taken at $415 \mathrm{~nm}$ using a spectrophotometer (Perkin Lambda 45).

2.18. DPPH Free Radical Scavenging Assay. The samples were prepared $(6-200 \mu \mathrm{g} / \mathrm{mL})$ and added to $100 \mu \mathrm{L}$ DPPH (1,1diphenyl-2-picrylhydrazyl) with a final concentration of $100 \mu \mathrm{M}$ DPPH. Absolute methanol was used as a negative control. All samples were incubated at $37^{\circ} \mathrm{C}$, and then, the absorbance was measured by a microplate reader at $512 \mathrm{~nm}$ (Thermolab Systems, Finland). Ascorbic acid (Vit C) was used as a standard [34].

\section{Results}

3.1. Viability Assay. MTT assay was performed on two cancer cell lines and one normal cell line, i.e., human colorectal carcinoma cell line (HCT-116), human hormonesensitive breast cancer cell line (MCF-7), and human hybrid endothelial cell line (EA.hy926). The screening test of $A$. lappa extracts (PT, ETH, and WT) showed that ETH was more active on MCF-7 compared to PT and WT extracts. The percentage of cell viability was $22.95 \pm 1.01(p<0.05)$ at a concentration of $100 \mu \mathrm{g} / \mathrm{mL}$. Moreover, ETH inhibited the proliferation of EA.hy 926 cells more than other extracts with a $35.53 \pm 0.64 \%$ cell viability. Following fractionation, the screening test was performed on MCF-7 and EA.hy926 cell lines for all ETH fractions (EHX, EEA, EB, and EW) at a concentration $100 \mu \mathrm{g} / \mathrm{mL}$. The results show that EHX was significantly the most cytotoxic compared to other extracts and fractions. The percentage of cell viability on MCF-7 and EA.hy926 was $16.1 \pm 1.81$ and $22.97 \pm 1.37(p<0.05)$, respectively (Table 1 ). The $\mathrm{IC}_{50}$ values are $14.08 \pm 3.64$ and
TABle 1: Percentage of cell viability by using MTT assay at a concentration $100 \mu \mathrm{g} / \mathrm{mL}$.

\begin{tabular}{lccc}
\hline Extract & MCF-7 & HCT-116 & EA.hy926 \\
\hline Petroleum ether (PT) & $29.25 \pm 1.55^{*}$ & $37.63 \pm 3.27^{*}$ & $59.75 \pm 3.22^{*}$ \\
Ethanol (ETH) & $22.95 \pm 1.01^{*}$ & $45.65 \pm 4.82^{*}$ & \\
$93.25 \pm 1.05$ & $35.53 \pm 0.64^{*}$ & & \\
Water (WT) & $88.11 \pm 2.2^{*}$ & & $89.97 \pm 3.65^{*}$ \\
$n$-Hexane (EHX) & $16.1 \pm 1.81^{*}$ & - & $22.97 \pm 1.37^{*}$ \\
Ethyl acetate (EEA) & $55.01 \pm 2.37^{*}$ & - & $60.77 \pm 1.89^{*}$ \\
Butanol (EB) & $70.63 \pm 1.66^{*}$ & - & $83.86 \pm 2.14^{*}$ \\
Water (EW) & $48.13 \pm 2.98^{*}$ & - & $56.68 \pm 2.22^{*}$ \\
Negative control & $100.01 \pm 2.07$ & $100.14 \pm 0.25$ & $100 \pm 2.11$ \\
\hline
\end{tabular}

${ }^{*} p<0.05$ relative to control; values are mean \pm SD.

$27.25 \pm 3.45 \mu \mathrm{g} / \mathrm{mL}$ for MCF-7 and EA.hy926, respectively. The positive control for MCF-7 was tamoxifen ( $\mathrm{IC}_{50}$ $11.04 \pm 1.31 \mu \mathrm{g} / \mathrm{mL}$ ), and that for EA.hy926 was betulinic acid ( IC $_{50} 4.27 \pm 0.38 \mu \mathrm{g} / \mathrm{mL}$ ) (Table 2).

\subsection{Proapoptotic Activity of EHX on MCF-7}

3.2.1. Morphological Changes of MCF-7 by the Hoechst Stain Test. This assay was conducted by using Hoechst 33258 dye which penetrates into cells' nuclei to stain the DNA [35]. The microimages illustrated manifestly cell shrinkage, kidney shape, and apoptotic body of the treated cells (Figure 1(a)). The apoptotic index was calculated for different concentrations $(7.5,15$, and $30 \mu \mathrm{g} / \mathrm{mL})$, and the results indicated a dose-dependent relation with apoptotic values. The apoptotic index values were significantly $(p<0.05)$ different as $25.13 \pm 5.87$ and $47.97 \pm 4.23 \%$ at concentrations of 15 and $30 \mu \mathrm{g} / \mathrm{mL}$, respectively, while the lower concentration $(7.5 \mu \mathrm{g} / \mathrm{mL})$ showed no significant difference $(21.58 \pm 4 \%)$.

\subsubsection{Ultrastructural Changes of MCF-7 by TEM. TEM was} performed to observe the ultrastructures of MCF-7. Cells were treated with EHX $(10 \mu \mathrm{g} / \mathrm{mL})$ for $24 \mathrm{~h}$, and microimages showed several signs of apoptosis induction compared to the control sample (Figures 2(a) and 2(b)). The normal cell morphology in the control sample was indicated as dense cellular content, diffused chromatin, and fewer vacuoles. On the other hand, the treated cell developed apoptotic changes such as condensed chromatin, floating nucleus content in the cytoplasm, apoptotic bodies, vacuoles with various sizes, and no nucleolus. This result suggests apoptotic cell death of MCF-7 cells upon EHX treatment [36].

3.2.3. Cell Signal Pathways. A dual-luciferase reporter system was used to evaluate 10 signal pathways involved in apoptosis and angiogenesis process (Figure 2(c)). The data indicated that EHX upregulated 3 pathways significantly $(p<0.05) . p 53 \quad(3.05$-fold $)$ is an important proapoptotic marker, TGF- $\beta$ (2.36-fold) has tumor suppressor properties, and NFkB (2.08-fold) is an essential contributor in proliferation, metastasis, and angiogenesis. However, no significant change was observed in other pathways such as Wnt 
TABLE 2: $\mathrm{IC}_{50}$ values $(\mu \mathrm{g} / \mathrm{mL})$ by using MTT assay.

\begin{tabular}{lcr}
\hline Extract & MCF-7 & EA.hy926 \\
\hline ETH & $50.18 \pm 3.66$ & - \\
EHX & $14.08 \pm 3.64$ & $27.25 \pm 3.45$ \\
Tamoxifen & $11.04 \pm 1.31$ & - \\
Betulinic acid & - & $4.27 \pm 0.38$ \\
\hline
\end{tabular}

Values are mean $\pm \mathrm{SD}$.

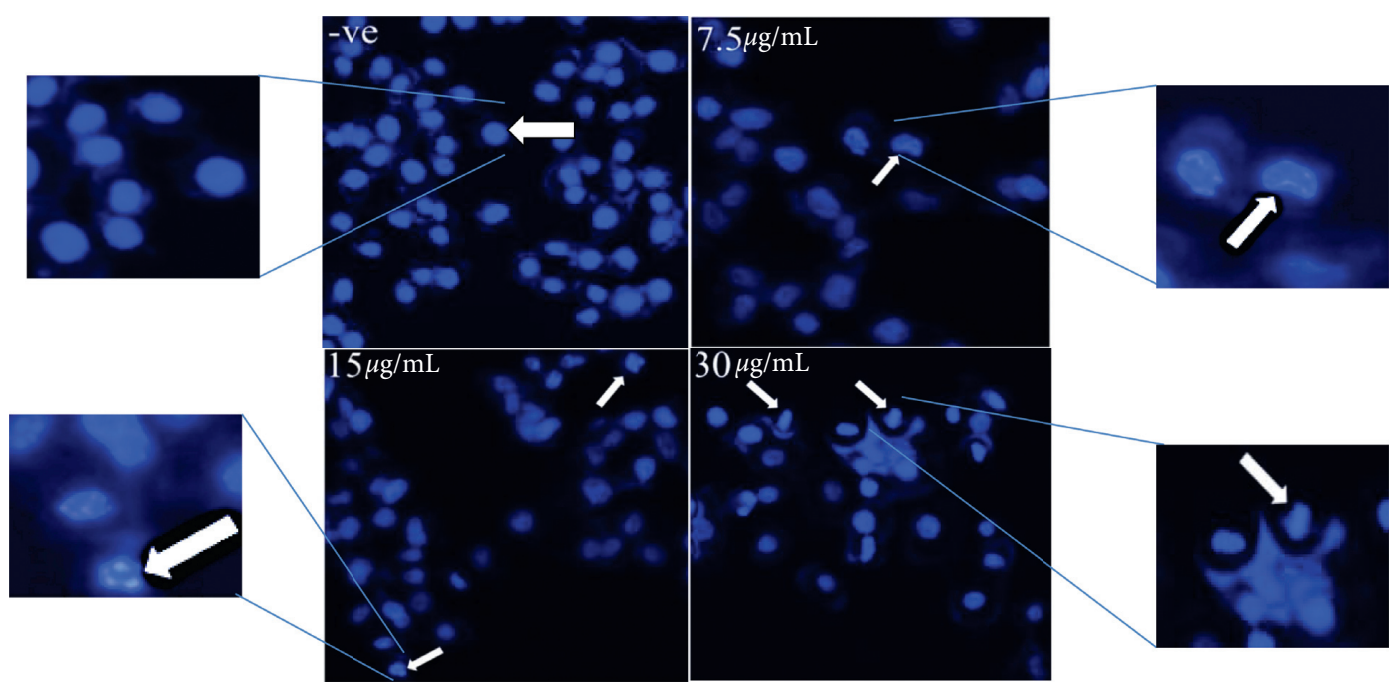

(a)

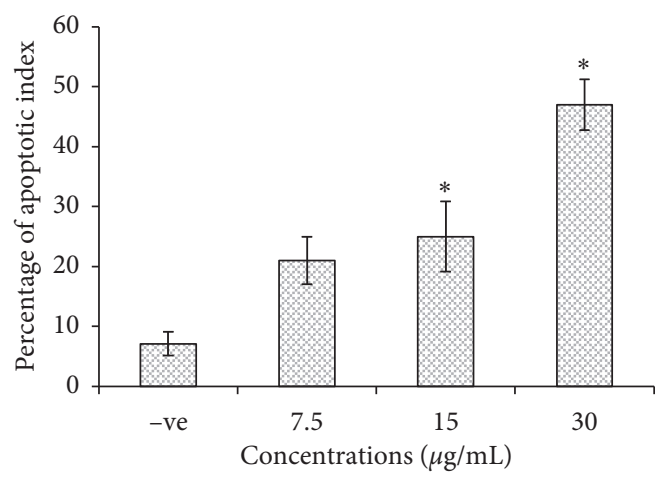

(b)

Figure 1: (a) MCF-7 cells in Hoechst stain demonstrate the normal morphology in the negative control (-ve) and the morphological changes in treated cells at different concentrations of EHX: kidney shape, apoptotic body, and cell shrinkage. Magnification is 20x. (b) Percentage of the apoptotic index at concentrations of $7.5,15$, and $30 \mu \mathrm{g} / \mathrm{mL}$. Values are mean \pm SD. ${ }^{*} p<0.05$.

(1.4-fold), Notch (1.14-fold), cell cycle (1.19-fold), Myc/Max (1.04-fold), HIF (0.93-fold), MAPK/ERK (1.51-fold), and MAPK/JNK (1.17-fold).

3.2.4. Colony Formation. The colony formation assay was performed in a 6-well plate using MCF-7 cells at a concentration of $500 \mathrm{cell} / \mathrm{mL}$ (Figure 3(a)). The efficacy was presented as cell surviving percentage and the results were inversely proportional to EHX concentrations $(0.875,1.75$, 3.5 , and $7 \mu \mathrm{g} / \mathrm{mL})$. EHX showed zero percent colonization at $7 \mu \mathrm{g} / \mathrm{mL}$. The cell survival percentage was $71.52 \pm 2.8$ and $25.49 \pm 4.21 \%$ for the concentrations of 1.75 and $3.5 \mu \mathrm{g} / \mathrm{mL}$, respectively $(p<0.05)$. However, there was no significant difference in cell survival percentage $(93.37 \pm 5.61 \%)$ for the concentration of $0.875 \mu \mathrm{g} / \mathrm{mL}$, compared to the negative control (Figure 3(b)). Tamoxifen $(10 \mu \mathrm{g} / \mathrm{mL})$ was used as a positive control, and it inhibited cell colonization by $100 \%$. Plating efficiency was $15.1 \pm 0.56 \%$.

3.2.5. Cell Invasion. MCF-7 cell invasion was evaluated using a matrigel basement. The data was presented as a cell survival percentage at EHX concentrations $(7.5$ and $15 \mu \mathrm{g} /$ $\mathrm{mL})$. Microimages exhibited a significant decrease in cell invasion in a dose-dependent manner (Figure 4(a)). Cell 


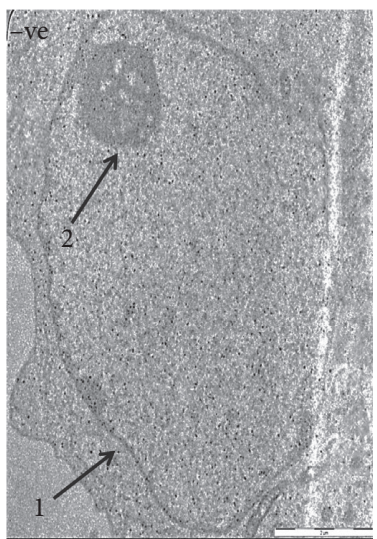

(a)

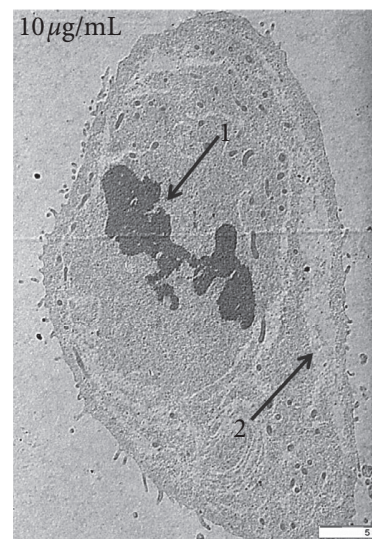

(b)

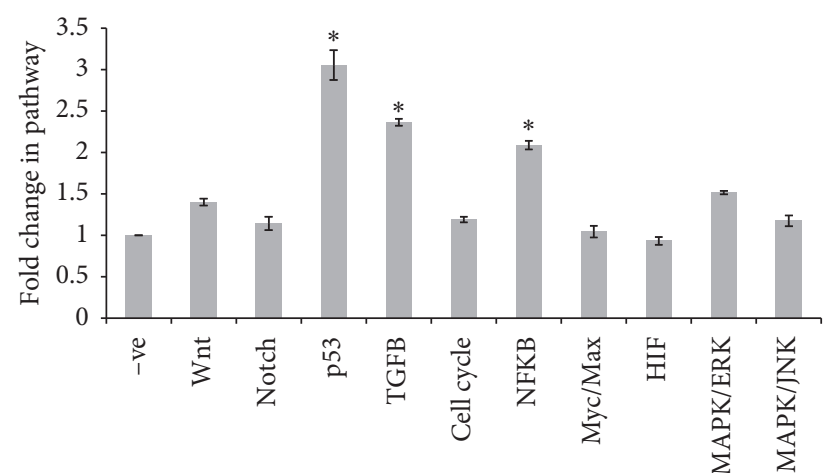

(c)

Figure 2: (a) TEM ultrastructural micrograph of untreated MCF-7 cells. 1. Nucleus. 2. Nucleolus. Magnification is 1600x. (b) Ultrastructural micrograph of MCF-7 cell after treatment by EHX $(10 \mu \mathrm{g} / \mathrm{mL})$. 1: chromatin condensation; 2: vacuoles. Magnification is 1250x. (c) The effect of EHX $(10 \mu \mathrm{g} / \mathrm{mL})$ on 10 signaling pathway activities. Values are mean $\pm \mathrm{SD} .{ }^{*} p<0.05$.
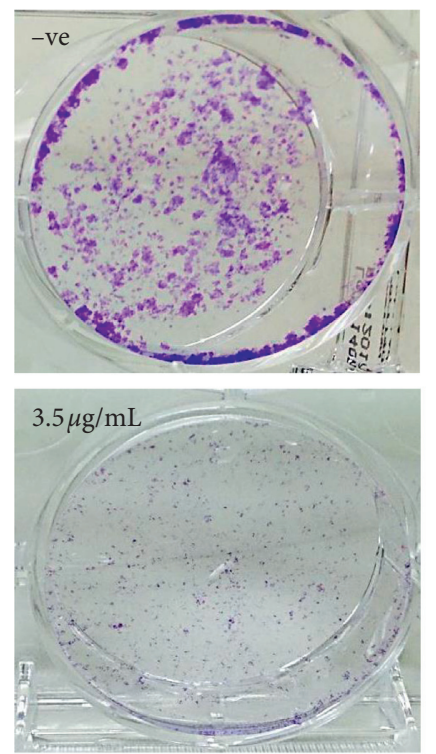

(a)
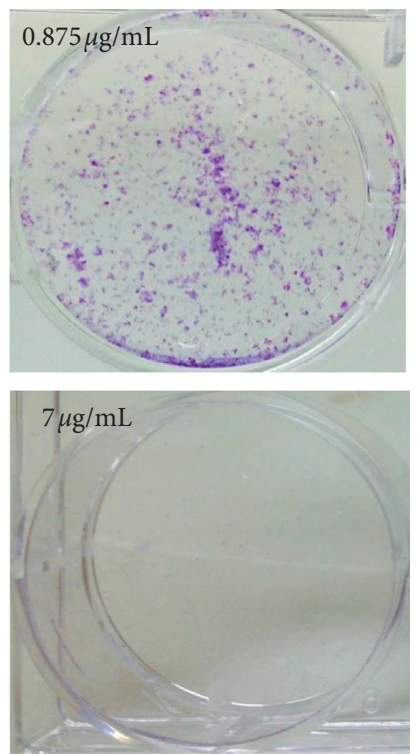

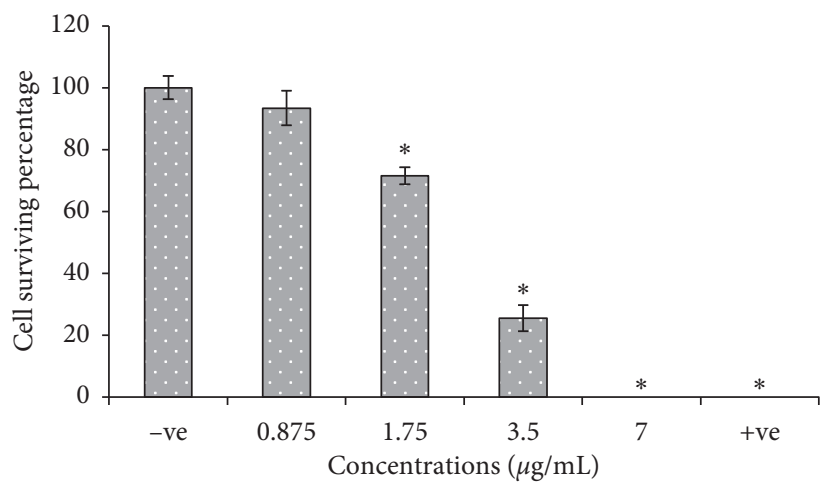

(b)

Figure 3: (a) MCF-7 cells in a colony formation assay. Cells were treated by ethanol (-ve) or EHX at different concentrations. (b) Percentage of cell surviving in colony formation assay. Tamoxifen $(10 \mu \mathrm{g} / \mathrm{mL})$ was used as a positive control $(+\mathrm{ve})$. Values are mean \pm SD. ${ }^{*} p<0.05$.

survival percentage was $45.35 \pm 2.04$ and $67.18 \pm 3.75 \%$, respectively $(p<0.05)$, compared to the control sample (Figure 4(b)).

3.2.6. Cell Migration. The migration ability of MCF-7 was tested at two time points ( $6 \mathrm{~h}$ and $12 \mathrm{~h}$ ) after EHX treatment at 15 and $30 \mu \mathrm{g} / \mathrm{mL}$. Wounds were created equally at zero hours for both concentrations (Figure 4(c)). After $6 \mathrm{~h}$ of treatment, cell migratory was inhibited significantly $(p<0.05)$ with values of $32.36 \pm 3.7$ and $45.02 \pm 2.1 \%$, respectively (Figure $4(\mathrm{~d})$ ), whereas the wound size became narrower compared to the untreated cells. After $12 \mathrm{~h}$ of treatment, no significant effect was indicated with $15 \mu \mathrm{g} / \mathrm{mL}$ concentration, whereas higher concentration $(30 \mu \mathrm{g} / \mathrm{mL})$ showed a significant inhibitory effect with a value of $37.14 \pm 0.96 \%(p<0.05)$. Tamoxifen was used as a positive control at a concentration of $10 \mu \mathrm{g} / \mathrm{mL}$. The untreated cells displayed more rapid wound closure at all time points, and the wound was completely closed after $12 \mathrm{~h}$ compared to the treated cells. The results suggested that EHX is able to inhibit in vitro cell migration of MCF-7 cells.

\subsection{Antiangiogenic Activity}

3.3.1. Rat Aorta Ring Assay. This assay was performed to evaluate the antiangiogenic activity of $A$. lappa extracts and 

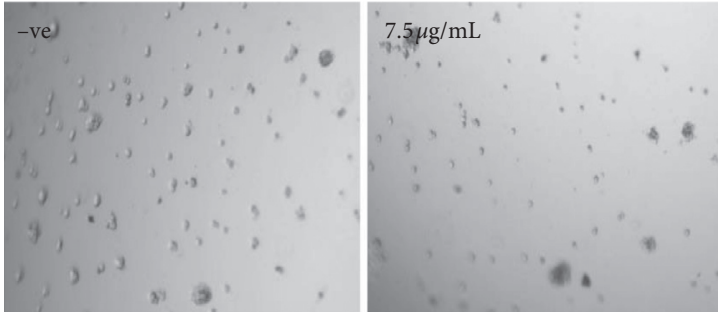

(a)

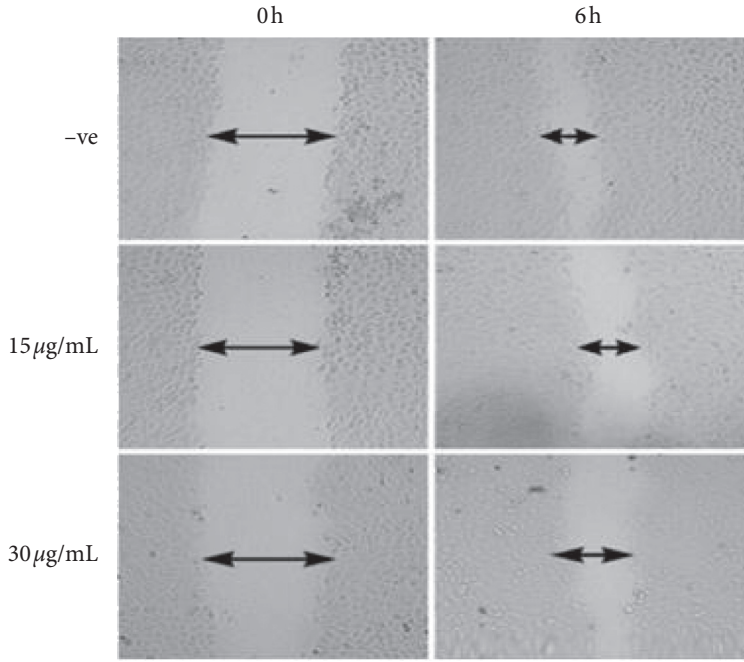

(c)
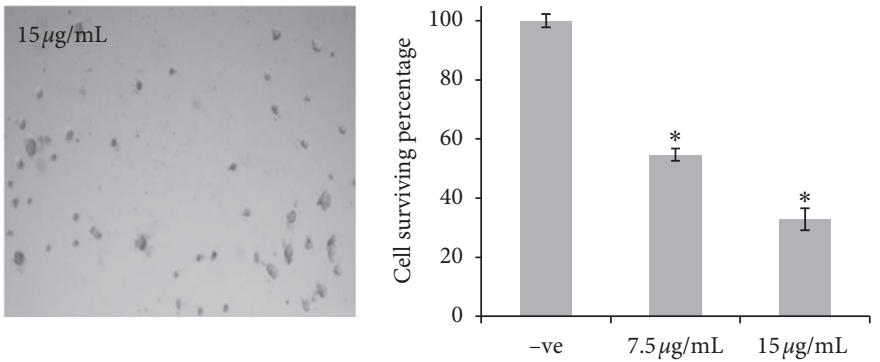

(b)

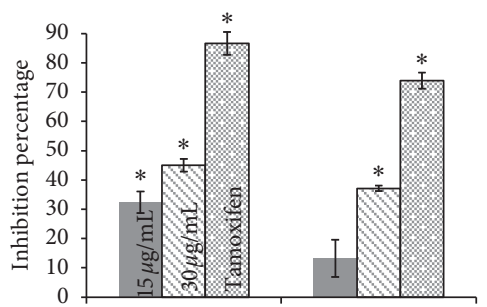

$6 \mathrm{~h}$

$12 \mathrm{~h}$

(d)

FIGURE 4: (a) Invasion assay of MCF-7 cells in matrigel basement. Cells were treated by ethanol (-ve) or EHX at different concentrations. Magnification is $4 \mathrm{x}$. (b) Percentage of cell surviving in invasion assay. Values are mean \pm SD. ${ }^{*} p<0.05$. (c) Cell migration assay of MCF-7. Cells were treated by ethanol for negative control (-ve) or EHX at different concentrations. Wound healing was observed at time points 0,6 , and 12 hours. Image s software was used to measure the wound size. Magnification is $4 \mathrm{x}$. (d) Percentage of inhibition of MCF-7 cells' migration after 6 and 12 hours of treatment. Tamoxifen $(10 \mu \mathrm{g} / \mathrm{mL})$ was used as a positive control. Values are mean \pm SD. ${ }^{*} p<0.05$.

fractions (Figures 5(a) and 5(b)). The data was presented as a percentage of inhibition of microvessel outgrowth from rat aortic rings. The extracts (PT, ETH, and WT) were initially tested at a single concentration of $100 \mu \mathrm{g} / \mathrm{mL}$ to determine the most active one (Table 3). The ethanol extract (ETH) showed the most potent effect $(58.75 \pm 2.84 \%)$ in comparison with other extracts $(p<0.05)$. Following fractionation, all ETH fractions (EHX, EEA, EB, and EW) were screened at the same concentration $(100 \mu \mathrm{g} / \mathrm{mL})$. Interestingly, EHX completely inhibited the microvessels sprouting activity $(100 \%)$, and it was significantly $(p<0.05)$ the most active compared to the other fractions. The $\mathrm{IC}_{50}$ value of EHX was $4.34 \pm 1.64 \mu \mathrm{g} / \mathrm{mL}$, and it was almost similar to the positive control (Suramin) with an $\mathrm{IC}_{50}$ value of $4.62 \pm 1.17 \mu \mathrm{g} / \mathrm{mL}$.

3.3.2. VEGF Expression by MCF-7. The EHX effect on rat aortic microvessels was supported by molecular findings specific to the angiogenesis process. The VEGF-165 protein expression was evaluated in MCF-7 cells using two concentrations of 15 and $30 \mu \mathrm{g} / \mathrm{mL}$. The results showed a significant $(p<0.05)$ inhibition in VEGF expression after $24 \mathrm{~h}$ (Figure 5(c)). The inhibition percentage of VEGF protein was $43.35 \pm 2.65$ and $54.61 \pm 3.59 \%$, respectively.

\subsection{Phytochemical Study}

3.4.1. GC-MS. GC-MS data of ETH and EHX was analyzed using MSD-ChemStation software (Agilent Technologies, USA). All compounds were identified by comparing to the reference of the NIST02 library (Figures 6(a) and 6(b)). Tables 4-6 elucidate (GC-MS) resulting chromatograms and mass spectra of probable constituents including major peaks of 22 identified compounds of ETH and 20 compounds of the EHX; they include the retention time (RT), percentages of area, identified compounds, their respective molecular weights, and molecular structures. Stigmasterol, $\beta$-sitosterol, and 3-O-acetyllupeol were the active compounds available in ETH and EHX in different percentages. The EHX fraction was found to have higher percentages of stigmasterol, $\beta$ sitosterol, and 3-O-acetyllupeol with 4.41, 6.34, and 5.56\%, respectively, while the percentages of the area in ETH extract were $2.49,3.82$, and $2.83 \%$, respectively.

3.4.2. Total Phenols. The total phenol content in the ethanol extract (ETH) and its fraction (EHX) was measured as $\mu \mathrm{g}$ of gallic acid equivalent to $\mathrm{mg}$ of extract (GAE eq/mg). The 

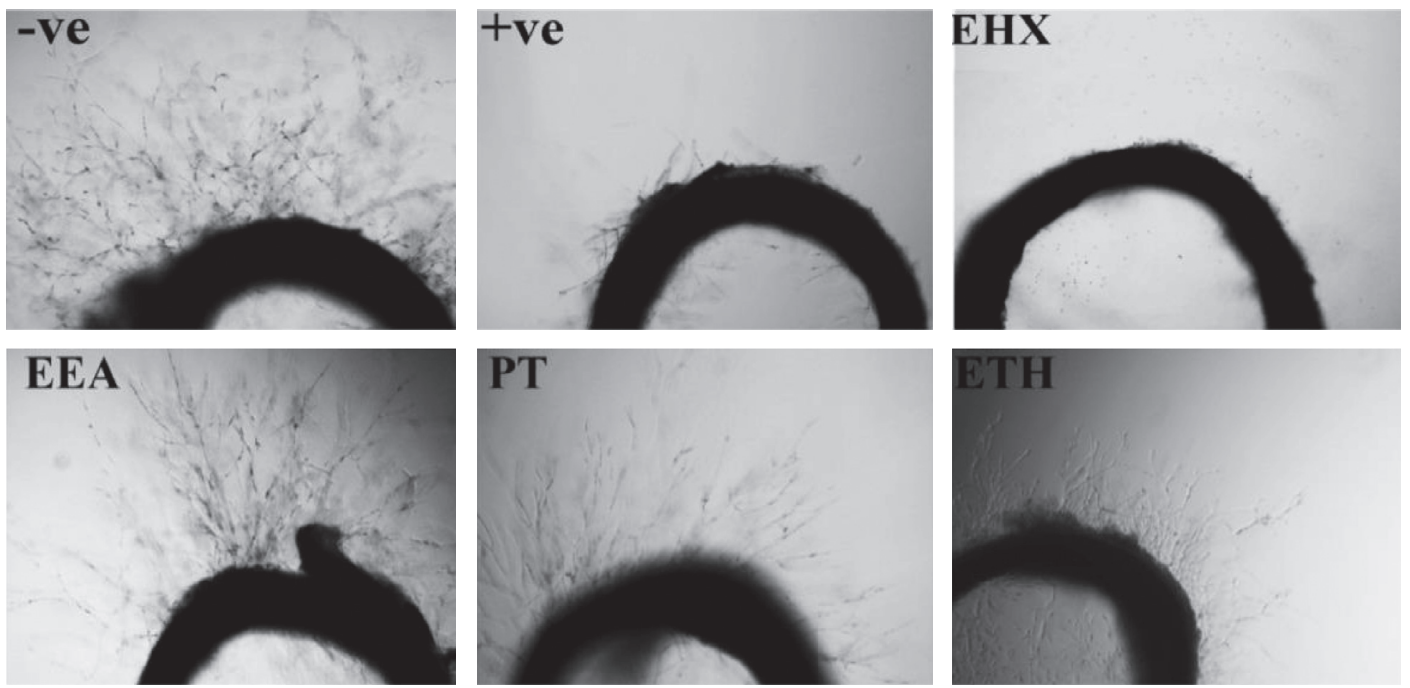

(a)
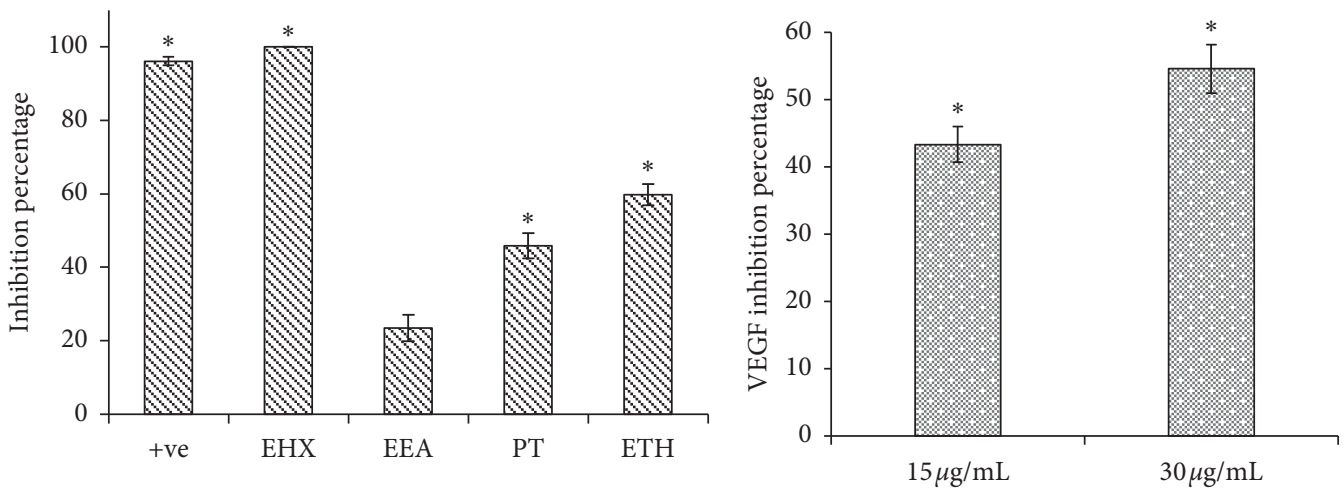

(b)

(c)

Figure 5: (a) Rat aortic ring assay. Rings were treated by ethanol (-ve), A. lappa extracts $(100 \mu \mathrm{g} / \mathrm{mL})$, or Suramin $(100 \mu \mathrm{g} / \mathrm{mL})(+\mathrm{ve})$, Microvessel outgrowth was measured by ImageJ software. Magnification is 4x. (b) Percentage of inhibition of microvessel outgrowth after treatment. Values are mean \pm SD. ${ }^{*} p<0.05$. (c) Percentage of inhibition of VEGF-A after EHX treatment $(15$ and $30 \mu \mathrm{g} / \mathrm{mL})$. Values are mean \pm SD. ${ }^{*} p<0.05$.

TABLE 3: Rat aorta ring assay percentage of inhibition at $100 \mu \mathrm{g} / \mathrm{mL}$ of extracts and the $\mathrm{IC}_{50}$ values $(\mu \mathrm{g} / \mathrm{mL})$.

\begin{tabular}{lcc}
\hline Extract & Inhibition percentage & $\mathrm{IC}_{50}$ value \\
\hline Petroleum ether (PT) & $45.88 \pm 3.42^{*}$ & - \\
Ethanol (ETH) & $59.75 \pm 2.84^{*}$ & $70.67 \pm 3.06$ \\
Water (WT) & $9.4 \pm 1.5$ & - \\
$n$-Hexane (EHX) & $100^{*}$ & $4.34 \pm 1.64$ \\
Ethyl acetate (EEA) & $23.5 \pm 3.61$ & - \\
Butanol (EB) & $4.42 \pm 1.33$ & - \\
Water (EW) & $29.73 \pm 4.08$ & - \\
Suramin (positive control) & - & $4.62 \pm 1.17$ \\
\hline
\end{tabular}

${ }^{*} p<0.05$ relative to control; values are mean $\pm \mathrm{SD}$.

total phenol content for ETH and EHX was $59.45 \pm 1.46$ and $64.59 \pm 0.89 \mu \mathrm{g}$ GAE eq/mg extract, respectively (Table 7 ).

3.4.3. Total Flavonoids. The total flavonoid content was measured as $\mu \mathrm{g}$ of quercetin equivalent to $\mathrm{mg}$ of extract (QAE eq/mg extract). The result for ETH and EHX was
$13.13 \pm 0.05$ and $32.10 \pm 1.15 \mu \mathrm{g}$ QAE eq/mg extract, respectively (Table 7).

3.4.4. DPPH Scavenging Activity. DPPH scavenging activity is presented as half-maximal inhibitory concentration $\left(\mathrm{IC}_{50}\right)$ of ETH extract and its fraction EHX. The $\mathrm{IC}_{50}$ value for $\mathrm{ETH}$ and EHX was $62 \pm 2.84 \mu \mathrm{g} / \mathrm{mL}$ and $35.04 \pm 0.21 \mu \mathrm{g} / \mathrm{mL}$, respectively. Ascorbic acid (Vit C) was used as a reference with $\mathrm{IC}_{50}$ of $3.83 \pm 0.03 \mu \mathrm{g} / \mathrm{mL}$.

\section{Discussion}

Previously, reports have revealed the anticancer activity of $A$. lappa on various cell lines such as mouse hepatoma carcinoma cells (HepA) and sarcoma cells (S180), human breast cancer cells (MCF-7), gastric adenocarcinoma cells (BGC823), mice spleen lymphocytes, and colorectal adenocarcinoma cells (Caco-2), [37, 38]. In this study, the aerial part of A. lappa was tested against two cancer cell lines (MCF-7 and HCT-116), and it is found to be more active against MCF-7. 


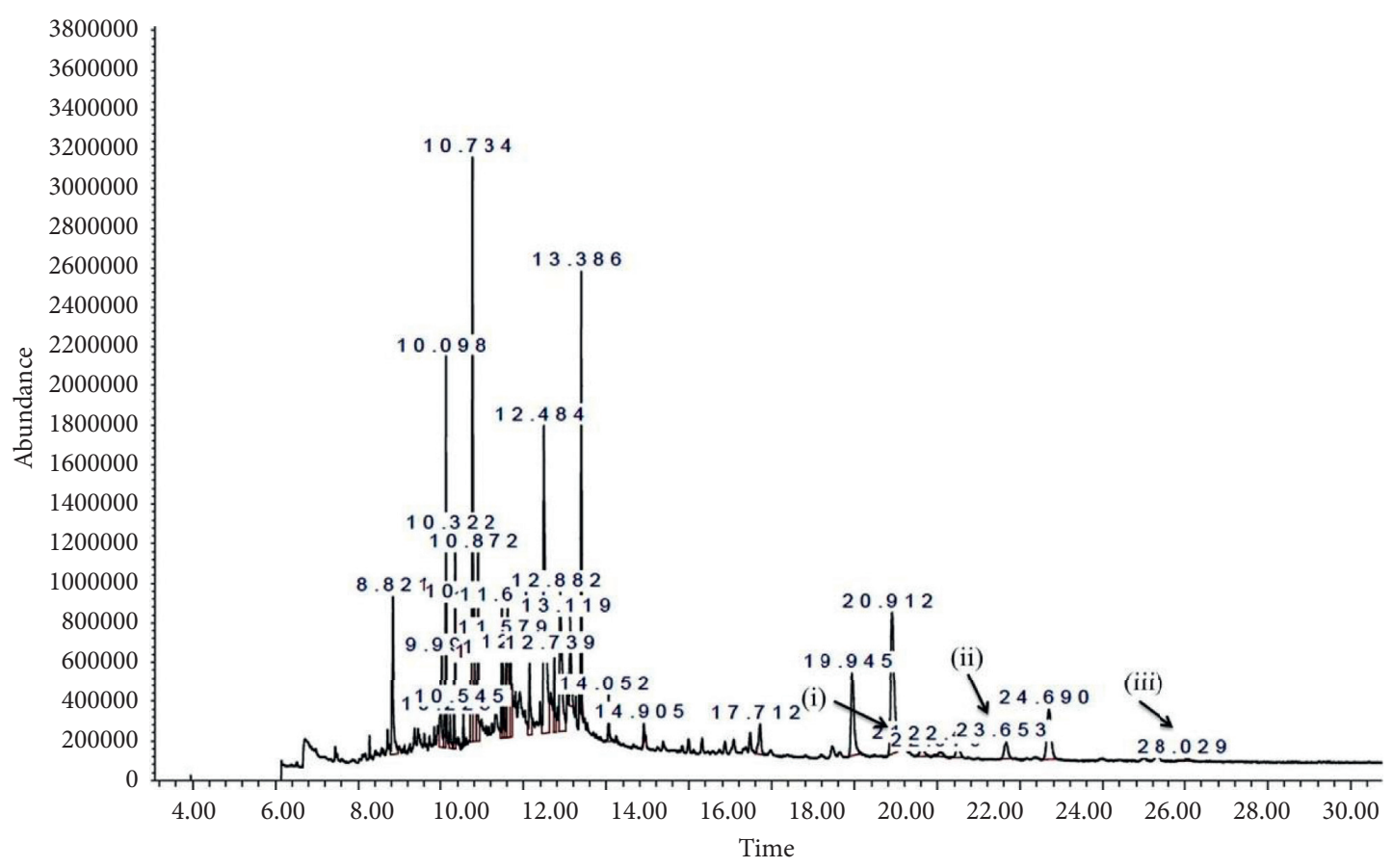

(a)

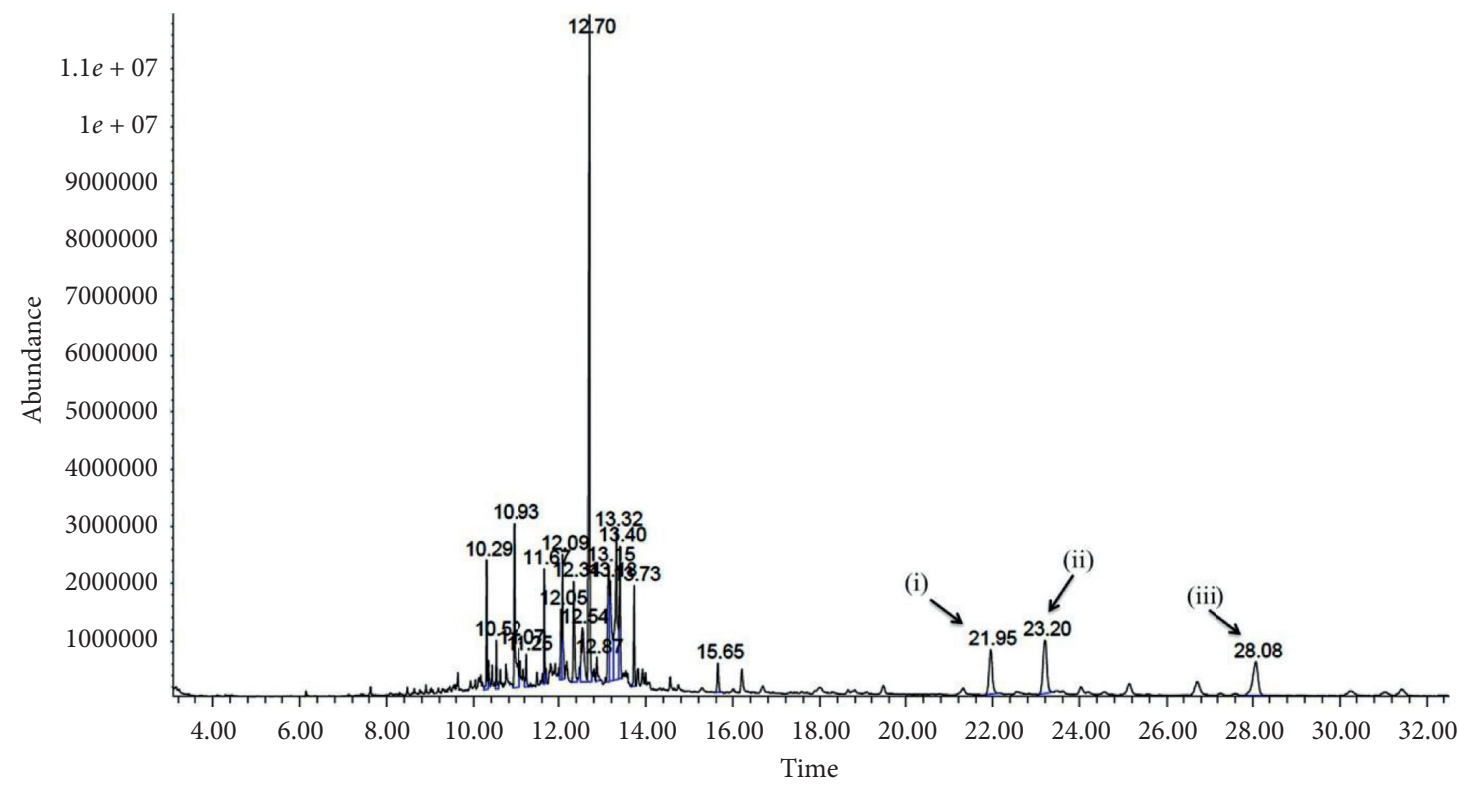

(b)

FIgure 6: (a) and (b) Mass spectrogram of ETH extract and EHX fraction, respectively. (i) Stigmasterol. (ii) $\beta$-Sitosterol. (iii) 3-OAcetyllupeol.

According to Machado et al. [37], the ethanol extract from A. lappa and its ethyl acetate fraction inhibited the proliferation of Caco- 2 better than the other extracts, and 3 subfractions out of 22 exhibited potent activity. Our results correspond well with the previous works on the anticancer activity of A. lappa. The ethanol extract (ETH) of A. lappa significantly inhibited the proliferation of MCF-7 compared to the other extracts. The $\mathrm{IC}_{50}$ value of ETH was $50.18 \pm 3.66 \mu \mathrm{g} / \mathrm{mL}$. Consequently, the antiproliferative activity progressively improved in $\mathrm{n}$-hexane fraction (EHX), which was obtained from the most active extract ETH. The efficacy of EHX was significantly better than other extracts and fractions against MCF-7 and EA.hy926. The $\mathrm{IC}_{50}$ values were $14.08 \pm 3.64$ and $27.25 \pm 3.45 \mu \mathrm{g} / \mathrm{mL}$, respectively. Indeed, A. lappa contains many therapeutic constituents including lignans, terpenoids, and sterols, which have versatile biological activities targeting cancer and pathological angiogenesis $[7,39,40]$. The phytosterols (stigmasterol and $\beta$ sitosterol) constituents have been proved in many studies as anticancer agents through various mechanisms of action, 
TABLE 4: Interpretation of GC-MS analysis: identified compounds that are contained in both ETH and EHX.

\begin{tabular}{|c|c|c|c|c|}
\hline $\mathrm{RT} / \mathrm{min}$ & Compound & Molecular formula & Molecular weight & Area\% \\
\hline 10.29 & Bicyclo[3.1.1]heptane,-2,6,6-trimethyl-,(1.alpha.,2.ß.,5.alpha.) & $\mathrm{C}_{10} \mathrm{H}_{18}$ & 138.24 & $1.68-2.55$ \\
\hline 10.94 & n-Hexadecanoic acid & $\mathrm{C}_{16} \mathrm{H}_{32} \mathrm{O}_{2}$ & 256.42 & $11.93-6.48$ \\
\hline 11.07 & Ethyl palmitate & $\mathrm{C}_{18} \mathrm{H}_{36} \mathrm{O}_{2}$ & 284.47 & $2.15-1.01$ \\
\hline 11.67 & Phytol & $\mathrm{C}_{20} \mathrm{H}_{40} \mathrm{O}$ & 296.53 & $1.92-2.04$ \\
\hline 13.18 & cis-(-)-2,4a,5,6,9a-Hexahydro-3,5,5,9-tetramethyl $(1 \mathrm{H})$ benzocycloheptene & $\mathrm{C}_{15} \mathrm{H}_{24}$ & 204.35 & $4.64-6.05$ \\
\hline 13.73 & Dioctyl phthalate & $\mathrm{C}_{24} \mathrm{H}_{38} \mathrm{O}_{4}$ & 390.55 & $4.77-2.71$ \\
\hline 21.95 & Stigmasterol & $\mathrm{C}_{29} \mathrm{H}_{48} \mathrm{O}$ & 412.69 & $2.49-4.41$ \\
\hline 23.2 & $\beta$-Sitosterol & $\mathrm{C}_{29} \mathrm{H}_{50} \mathrm{O}$ & 414.7 & $3.82-6.34$ \\
\hline 28.08 & 3-O-Acetyllupeol & $\mathrm{C}_{32} \mathrm{H}_{52} \mathrm{O}_{2}$ & 468.75 & $2.83-5.56$ \\
\hline
\end{tabular}

TABLE 5: Interpretation of GC-MS analysis: identified compounds that are contained in ETH only.

\begin{tabular}{|c|c|c|c|c|c|}
\hline Peak no. & $\mathrm{RT} / \mathrm{min}$ & Compound & Molecular formula & Molecular weight & Area\% \\
\hline 1 & 5.03 & Propane, 1,1,3-triethoxy- & $\mathrm{C}_{9} \mathrm{H}_{20} \mathrm{O}_{3}$ & 176.25 & 2.76 \\
\hline 2 & 8.82 & Diethyl phthalate & $\mathrm{C}_{12} \mathrm{H}_{14} \mathrm{O}_{4}$ & 222.23 & 1.96 \\
\hline 3 & 9.99 & Cyclononasiloxane, octadecamethyl- & C18H54O9Si9 & 667.38 & 1.13 \\
\hline 5 & 10.32 & 3,7,11,15-Tetramethyl-2-hexadecen- 1-ol & $\mathrm{C}_{20} \mathrm{H}_{40} \mathrm{O}$ & 296.53 & 0.67 \\
\hline 6 & 10.54 & Hexadecanoic acid, methyl ester & $\mathrm{C}_{17} \mathrm{H}_{34} \mathrm{O}_{2}$ & 270.45 & 0.41 \\
\hline 9 & 11.40 & 7-Octadecenoic acid, methyl ester & $\mathrm{C}_{19} \mathrm{H}_{36} \mathrm{O}_{2}$ & 296.48 & 1.34 \\
\hline 11 & 11.61 & 6-Octadecenoic acid & $\mathrm{C}_{18} \mathrm{H}_{34} \mathrm{O}_{2}$ & 282.46 & 18.55 \\
\hline 12 & 11.71 & Ethyl oleate & $\mathrm{C}_{20} \mathrm{H}_{38}$ & 310.51 & 13.66 \\
\hline 13 & 11.80 & Octadecanoic acid, ethyl ester & $\mathrm{C}_{20} \mathrm{H}_{40} \mathrm{O}_{2}$ & 312.53 & 1.42 \\
\hline 15 & 12.48 & Phenol, 4-(methylamino)- & $\mathrm{C}_{7} \mathrm{H}_{9} \mathrm{NO}$ & 123.15 & 6.18 \\
\hline 18 & 12.74 & 1,1,1,5,7,7,7-Heptamethyl-3,3-bis (trimethylsiloxy)tetrasiloxane & $\mathrm{C}_{13} \mathrm{H}_{40} \mathrm{O}_{5} \mathrm{Si}_{6}$ & 444.96 & 0.69 \\
\hline 20 & 13.05 & Naphthalene & $\mathrm{C}_{10} \mathrm{H}_{8}$ & 128.17 & 1.50 \\
\hline 25 & 14.14 & 2,3-Dihydroxypropyl elaidate & $\mathrm{C}_{21} \mathrm{H}_{40} \mathrm{O}_{4}$ & 356.54 & 2.68 \\
\hline
\end{tabular}

TABLE 6: Interpretation of GC-MS analysis: identified compounds that are contained in EHX only.

\begin{tabular}{|c|c|c|c|c|c|}
\hline Peak no. & $\mathrm{RT} / \mathrm{min}$ & Compound & Molecular formula & Molecular weight & Area\% \\
\hline 5 & 11.25 & Himachala-2,4-diene & $\mathrm{C}_{15} \mathrm{H}_{24}$ & 204.35 & 1.02 \\
\hline 7 & 12.05 & Parthenolide & $\mathrm{C}_{15} \mathrm{H}_{20} \mathrm{O}_{3}$ & 248.31 & 2.07 \\
\hline 8 & 12.08 & Arteannuin $b$ & $\mathrm{C}_{15} \mathrm{H}_{20} \mathrm{O}_{3}$ & 248.31 & 3.61 \\
\hline 9 & 12.35 & Epiglobulol & $\mathrm{C}_{15} \mathrm{H}_{26} \mathrm{O}$ & 222.36 & 4.20 \\
\hline 10 & 12.54 & 4,4,5,8-Tetramethyl-chroman-2-one & $\mathrm{C}_{13} \mathrm{H}_{16} \mathrm{O}_{2}$ & 204.26 & 5.03 \\
\hline 11 & 12.71 & Pyridine, 2-butyl & $\mathrm{C}_{9} \mathrm{H}_{13} \mathrm{~N}$ & 135.2 & 22.48 \\
\hline 12 & 12.87 & 2,4,6-Trimethyl-1,3-phenylenediamine & $\left(\mathrm{CH}_{3}\right)_{3} \mathrm{C}_{6} \mathrm{H}\left(\mathrm{NH}_{2}\right)_{2}$ & 150.22 & 0.91 \\
\hline 13 & 13.15 & 1S,2S,5R-1,4,4-Trimethyltricyclo[6.3.1.0(2,5)] dodec-8(9)-ene & $\mathrm{C}_{15} \mathrm{H}_{24}$ & 204.35 & 5.77 \\
\hline 15 & 13.32 & Spathulenol & $\mathrm{C}_{15} \mathrm{H}_{24} \mathrm{O}$ & 220.35 & 10.12 \\
\hline 16 & 13.4 & 4-Camphenylbutan-2-one & $\mathrm{C}_{14} \mathrm{H}_{22} \mathrm{O}$ & 206.32 & 4.79 \\
\hline 18 & 15.65 & Squalene & $\mathrm{C}_{30} \mathrm{H}_{50}$ & 410.71 & 1.32 \\
\hline
\end{tabular}

TABLE 7: Antioxidant activity of ETH extract and its fraction EHX.

\begin{tabular}{lccc}
\hline Extract & $\mathrm{DPPH} \mathrm{IC}_{50}(\mu \mathrm{g} / \mathrm{mL})$ & Total phenols $(\mu \mathrm{g} / \mathrm{mg})$ & Total flavonoids $(\mu \mathrm{g} / \mathrm{mg})$ \\
\hline ETH & $62 \pm 2.84$ & $59.45 \pm 1.46$ & $13.13 \pm 0.05$ \\
EHX & $35.04 \pm 0.21$ & $64.59 \pm 0.89$ & $32.10 \pm 1.15$ \\
Ascorbic acid & $3.83 \pm 0.03$ & - & - \\
\hline
\end{tabular}

Values are mean \pm SD.

such as inhibiting cancer cell growth and inducing cancer cell apoptosis [40-42]. Therefore, it can be speculated that these compounds are a cause of the antiproliferative activity of A. lappa, and the different percentages of the area by the gas chromatogram may explain the lower $\mathrm{IC}_{50}$ of $\mathrm{EHX}$ compared to the ETH extract. 
The Hoechst stain assay exhibited a clear morphological alteration, under a fluorescent microscope, in treated cells such as cell shrinkage, kidney shape, and apoptotic body compared to the untreated cells. This result was supported by an ultrastructural analysis from a transmission electron microscope. The microimages of treated cells illustrated the apoptotic changes compared to the control sample: condensed chromatin, floating nucleus content in the cytoplasm, apoptotic bodies, vacuoles with various sizes, and no nucleolus. This strongly suggests that cell death happened due to apoptosis induction in breast cancer cells [36, 43].

Moreover, the effect of EHX was tested on 10 cancer signal pathways related to the apoptosis and angiogenesis process. The data indicated that EHX significantly upregulated 3 pathways (p53, TGF $\beta$, and $N F k B$ ). p53 is a tumor suppressor gene that is critically involved in cell cycle regulation and apoptosis. [44]. The overexpression of p53 causes cell cycle arrest or induction of apoptotic cell death. p53 controls cell death through two apoptotic pathways: activation of death receptor DR-5 and Fas genes, which are related to the extrinsic pathway, and activation of Bak, Bax, and Bid proteins, which are related to the mitochondrial pathway [14]. This indicates that the proapoptotic activity of EHX against MCF-7 may be attributed to the activation of the 553 pathway.

TGF $\beta$ is a major tumor suppressor, and the absence of this protein increases the risk of developing cancer. Pierce et al. [45] found that mice tend to be more resistant to mammary tumor formation when TGF $\beta$ is hyperactivated, in addition to the tumor regression effect. Further researches suggested that the overexpression of TGF- $\beta$ in breast cancer cells is able to suppress tumor development markedly $[46,47]$. Our EHX fraction upregulated TGF $\beta$ significantly in MCF-7. This might be a reason behind the anticancer efficacy of EHX towards MCF-7 cells.

$\mathrm{NF}-\kappa \mathrm{B}$ acts as a guardian for malignant cells against apoptosis. Many studies have highlighted the important role of the NF- $\kappa \mathrm{B}$ pathway in cell growth, angiogenesis, and cell death suppression, and it is considered as a potential cancer drug target to curb malignancy [48]. Nevertheless, recent researches have challenged this idea because studies employing tumor models have shown that NF- $\kappa \mathrm{B}$ activation may also work against tumorigenesis. Interestingly, NF- $\kappa \mathrm{B}$ is directly connected to Fas expression, which is a member of the death receptor family. The canonical NF- $\kappa \mathrm{B}$ pathway was found to be a Fas transcription activator and it leads to induce apoptotic cell signals such as caspase 8 [49]. In another study, the nonsteroidal anti-inflammatory drug (aspirin) has been reported to upregulate this pathway through nuclear translocation of NF- $\kappa \mathrm{B}$ complexes to induce apoptotic cell death [50]. This result corresponds to the aspirin mechanism in apoptosis induction. A. lappa was reported to have anti-inflammatory properties, which are also evident in aspirin when exposed to cancer cells. This strongly suggests that the apoptotic cell death in MCF-7 may be initiated by the activation of the NF- $\kappa$ B pathway $[43,51]$.

Further investigations were conducted on MCF-7 cells to understand the anticancer activity of EHX including colony formation, cell migration, and invasion assays. The metastatic cancer cells start with cell proliferation followed by migration. Cancer cells must be able to tolerate the hemodynamic stress and avoid the natural host immune response, and in order to reach distant organs, tumor cells have to adapt to the new microenvironment and start colonization along with a network of new blood vessels (angiogenesis) to supply them with vital oxygen and nutrients. Thus, failure in one of these steps can halt the metastatic tumor growth process. The colony formation assay was performed to determine whether the effect of EHX is cytotoxic or cytostatic [52]. The cell survival percentage of MCF-7 cells was zero at high concentration $(7 \mu \mathrm{g} / \mathrm{mL})$, where EHX perturbs single cells to survive and to form colonies and thus confirms the cytotoxic effect. However, EHX at lower concentrations $(1.75$ and $0.875 \mu \mathrm{g} / \mathrm{mL})$ behaved as a cytostatic agent, where clonogenic cells started to revive upon the removal of EHX exposure. Cell migration was tested in vitro at two concentrations $(15$ and $30 \mu \mathrm{g} / \mathrm{mL})$. The lower concentration of EHX significantly inhibited MCF-7 to migrate to the other side of the wound during $6 \mathrm{~h}$, but its inhibitory effect was markedly decreased after $12 \mathrm{~h}$. Higher concentration had a stronger and significant inhibitory effect at all time points, and its wound remained open compared to the control sample, suggesting that EHX might disrupt the migration mechanism of breast cancer cells. Invasion of cancer cells into neighboring tissues and the vasculature plays an essential role in tumor metastasis. Cells tend to degrade the vascular subendothelial basement membrane to enter the bloodstream and to spread out to other body parts $[53,54]$. Cell invasion assay was performed in the matrigel basement at concentrations of 7.5 and $15 \mu \mathrm{g} /$ mL. EHX inhibited the invasion of MCF-7 significantly at both concentrations. The results indicated that EHX might attenuate MCF-7 metastasis ability through the inhibitory effect in cell migration and invasion process. According to Awad et al. [6], phytosterols such as $\beta$-sitosterol reduce the growth and metastasis of breast and pancreatic cancer cells in SCID mice, suggesting that the inhibitory effect of MCF-7 migration and invasion might be attributed to sterols constituents (stigmasterol and $\beta$-sitosterol) of EHX.

A tumor can lie quiescent and clinically undetectable in the body for many years, but under certain circumstances, cancer cells can turn to the active phase and start to proliferate, metastasize, and induce angiogenesis. This switch may occur when the body's immune system is weakened or/ and the stimulators such as VEGF (which regulate endothelial cell proliferation) and integrins (which control cell migration) outweigh the inhibitors [55]. The rat aorta ring assay was used to assess the antiangiogenic activity of EHX and the results revealed a potent inhibition with $\mathrm{IC}_{50}$ value $4.34 \pm 1.64 \mu \mathrm{g} / \mathrm{mL}$. The process of angiogenesis is dependent on the presence of free radicals that help to activate the VEGF expression. VEGF production increases to obtain an adequate amount of oxygen in the tumor hypoxic region, leading to the activation of the angiogenesis process. This process is regulated by HIF- $1 \alpha$ and HIF- $1 \beta$ which dimerize and translocate into the nucleus leading to the activation of VEGF expression [56]. The result of this study shows a decrease in VEGF protein expression levels in MCF-7 cells. 
The ex vivo studies using the rat aorta ring also show that EHX causes inhibition on neovascularization. So, the antiangiogenic activity of EHX may be acquired in consequence of the downregulation of VEGF expression. It is noteworthy that lupeol showed potent antiangiogenic properties in in vitro and in vivo studies and inhibited the expression of VEGF-A [8], and it could be behind the antiangiogenic activity of EHX. Furthermore, the effective role of oxidative stress in pathological angiogenesis related to tumors has been discovered through various connections and studies, elucidating that the oxidation mechanism plays a mediator role to release signals contributing in different angiogenicrelated responses [57]. A. lappa is a plant rich with phenols and flavonoids which act as reducing agents by neutralizing the free radicals [58]. In this study, the total phenols, flavonoids, and antioxidant activity were measured, and the results have proved strong antioxidant properties. Therefore, the antiangiogenic activity may be attributed to the quenching ability of polyphenols present in this plant.

\section{Conclusion}

This study shows that A. lappa fraction (EHX) has an in vitro cytotoxic and proapoptotic effect towards MCF-7 breast cancer cells, and it can inhibit cell colonization, migration, and invasion. EHX upregulated 3 pathways (p53, TGF- $\beta$, and NF-k $\beta$ ) associated with an antitumor property. Furthermore, the antiangiogenic activity of $A$. lappa displayed a potent effect on microblood vessel outgrowth and it downregulated the VEGF-A expression. In conclusion, the present work reveals promising anticancer and antiangiogenic activity of $A$. lappa. Thus, further research is needed to determine the anticancer effect in animal models.

\section{Data Availability}

The data used in this study to support our findings are available from the corresponding author upon request.

\section{Conflicts of Interest}

The authors declare no conflicts of interest.

\section{Acknowledgments}

This study was supported by the Research University Team (RUT) grant number 1001/PFARMASI/851001, Eman Biodiscoveries, Natureceuticals Sdn Bhd.

\section{References}

[1] C. JianFeng, Z. PengYing, X. ChengWei, H. TaoTao, B. YunGui, and C. KaoShan, "Effect of aqueous extract of Arctium lappa L.(burdock) roots on the sexual behavior of male rats," BMC Complementary and Alternative Medicine, vol. 12, no. 1, p. 1, 2012.

[2] Y. Cai, Q. Luo, M. Sun, and H. Corke, "Antioxidant activity and phenolic compounds of 112 traditional Chinese medicinal plants associated with anticancer," Life Sciences, vol. 74, no. 17, pp. 2157-2184, 2004.
[3] J. H. Lee, C. Kim, J. Lee, J.-Y. Um, G. Sethi, and K. S. Ahn, "Arctiin is a pharmacological inhibitor of STAT3 phosphorylation at tyrosine 705 residue and potentiates bortezomib-induced apoptotic and anti-angiogenic effects in human multiple myeloma cells," Phytomedicine, vol. 55, pp. 282-292, 2019.

[4] F. Khakdan, K. Piri, and A. F. Talebi, "Antiproliferative activity of aqueous extract from Arictum lappa L. root in human erythroleukemia cell line (k562) and lymphocyte cell," Life Sciences Journal, vol. 10, no. 6s, pp. 656-661, 2013.

[5] E. Catalano, "Cytotoxic activity of a plant extract on cancer cells," Italian Journal of Anatomy and Embryology, vol. 118, no. 2, p. 50, 2013.

[6] A. B. Awad, C. S. Fink, H. Williams, and U. Kim, "In vitro and in vivo (SCID mice) effects of phytosterols on the growth and dissemination of human prostate cancer PC-3 cells," European Journal of Cancer Prevention, vol. 10, no. 6, pp. 507-513, 2001.

[7] Y.-J. You, N.-H. Nam, Y. Kim, K.-H. Bae, and B.-Z. Ahn, "Antiangiogenic activity of lupeol from Bombax ceiba," Phytotherapy Research, vol. 17, no. 4, pp. 341-344, 2003.

[8] B. V. Avin, T. Prabhu, C. K. Ramesh et al., "New role of lupeol in reticence of angiogenesis, the cellular parameter of neoplastic progression in tumorigenesis models through altered gene expression," Biochemical and Biophysical Research Communications, vol. 448, no. 2, pp. 139-144, 2014.

[9] National Institutes of Health; National Cancer Institute, Surveillance, Epidemiology, and End Results Program. Cancer stat facts: female breast cancer, National Cancer Institute, NIH, Bethesda, MD, USA, 2020.

[10] A. G. Waks and E. P. Winer, "Breast cancer treatment," JAMA, vol. 321, no. 3, pp. 288-300, 2019.

[11] C. A. Parise and V. Caggiano, "Breast cancer survival defined by the ER/PR/HER2 subtypes and a surrogate classification according to tumor grade and immunohistochemical biomarkers," Journal of Cancer Epidemiology, vol. 2014, Article ID 469251, 11 pages, 2014.

[12] M. O. Hengartner, "The biochemistry of apoptosis," Nature, vol. 407, no. 6805, pp. 770-776, 2000.

[13] F. Esposito, M. Tornincasa, P. Chieffi, I. De Martino, G. M. Pierantoni, and A. Fusco, "High-mobility group A1 proteins regulate p53-mediated transcription of Bcl-2 gene," Cancer Research, vol. 70, no. 13, pp. 5379-5388, 2010.

[14] L. Yamasaki, "Role of the RB tumor suppressor in cancer," in Signal Transduction in Cancer, D. A. Frank, Ed., Springer, Boston, MA, USA, pp. 209-239, 2003.

[15] J. Wagner, C. L. Kline, and W. El-Deiry, "Resistance to TRAIL pathway-targeted therapeutics in cancer," in TRAIL, Fas $L i$ gand, TNF and TLR3 in Cancer, pp. 1-25, Springer, Berlin, Germany, 2017.

[16] A. Soleimani, M. Khazaei, G. A. Ferns, M. Ryzhikov, A. Avan, and S. M. Hassanian, "Role of TGF- $\beta$ signaling regulatory microRNAs in the pathogenesis of colorectal cancer," Journal of Cellular Physiology, vol. 234, no. 9, pp. 14574-14580, 2019.

[17] X. Pei, M. Li, J. Zhan et al., "Enhanced IMP3 expression activates NF-KB pathway and promotes renal cell carcinoma progression," PloS One, vol. 10, no. 4, Article ID e0124338, 2015.

[18] C. Hopirtean and V. Nagy, "Optimizing the use of anti VEGF targeted therapies in patients with metastatic colorectal cancer: review of literature," Medicine and Pharmacy Reports, vol. 91, no. 1, pp. 12-17, 2018.

[19] L. E. A. Hassan et al., "Correlation of antiangiogenic, antioxidant and cytotoxic activities of some Sudanese medicinal 
plants with phenolic and flavonoid contents," BMC Complementary and Alternative Medicine, vol. 14, no. 1, p. 1, 2014.

[20] M. S. Lee, I. I. Lee, Y. Kim, Y. J. Kim, H. J. Heo, and D.-O. Kim, "Inhibitory effect of the ethyl acetate fraction from astringent persimmon on H2O2-induced oxidative stress in HepG2 cells," Food Science and Biotechnology, vol. 23, no. 4, pp. 1247-1252, 2014.

[21] H. M. Baharetha, Z. D. Nassar, A. F. Aisha et al., "Proapoptotic and antimetastatic properties of supercritical $\mathrm{CO} 2$ extract of Nigella sativa Linn. against breast cancer cells," Journal of Medicinal Food, vol. 16, no. 12, pp. 1121-1130, 2013.

[22] S. Y. Hussaini, R. A. Haque, P. O. Asekunowo, A. M. S. Abdul Majid, M. Taleb Agha, and M. R. Razali, "Synthesis, characterization and anti-proliferative activity of propylene linked bis-benzimidazolium salts and their respective dinuclear Silver(I)- N -heterocyclic carbene complexes," Journal of Organometallic Chemistry, vol. 840, pp. 56-62, 2017.

[23] J. Mu, T. Liu, L. Jiang et al., "The traditional Chinese medicine baicalein potently inhibits gastric cancer cells," Journal of Cancer, vol. 7, no. 4, pp. 453-461, 2016.

[24] J. M. Frasca and V. R. Parks, "A routine technique for doublestaining ultrathin sections using uranyl and lead salts," The Journal of Cell Biology, vol. 25, no. 1, pp. 157-161, 1965.

[25] N. A. P. Franken, H. M. Rodermond, J. Stap, J. Haveman, and C. van Bree, "Clonogenic assay of cells in vitro," Nature Protocols, vol. 1, no. 5, pp. 2315-2319, 2006.

[26] T. Fatima, R. A. Haque, M. A. Iqbal et al., "Tetra N -heterocyclic carbene dinuclear silver(I) complexes as potential anticancer agents: synthesis and in vitro anticancer studies," Journal of Organometallic Chemistry, vol. 853, pp. 122-135, 2017.

[27] A. Hamidi, J. Song, N. Thakur et al., “TGF- $\beta$ promotes PI3KAKT signaling and prostate cancer cell migration through the TRAF6-mediated ubiquitylation of p $85 \alpha$," Science Signaling, vol. 10, no. 486, Article ID eaal4186, 2017.

[28] Y. M. Tabana, F. S. R. Al-Suede, M. B. Khadeer et al., "Cat's whiskers (Orthosiphon stamineus) tea modulates arthritis pathogenesis via the angiogenesis and inflammatory cascade," BMC Complementary and Alternative Medicine, vol. 16, no. 1, p. 480, 2016.

[29] G. Bocci, R. Danesi, U. Benelli et al., "Inhibitory effect of suramin in rat models of angiogenesis in vitro and in vivo," Cancer Chemotherapy and Pharmacology, vol. 43, no. 3, pp. 205-212, 1999.

[30] F. G. Kitson, B. S. Larsen, and C. N. McEwen, Gas Chromatography and Mass Spectrometry: A Practical Guide, Academic Press, San Diego, CA, USA, 1996.

[31] L. J. Lizcano, F. Bakkali, M. Begoña Ruiz-Larrea, and J. Ignacio Ruiz-Sanz, "Antioxidant activity and polyphenol content of aqueous extracts from Colombian Amazonian plants with medicinal use," Food Chemistry, vol. 119, no. 4, pp. 1566-1570, 2010.

[32] H. Baharetha and Z. D. Nassar, "Use of nigella sativa linn. supercritical carbon dioxide extract for targeting the angiogenesis cascade," Medicinal \& Aromatic Plants, vol. 5, no. 3, pp. 2167-0412, 2016.

[33] Y. M. Tabana, S. S. Dahham, and L. Ahmed Hassan, "In Vitro anti-metastatic and antioxidant activity of nicotiana glauca fraction against breast cancer cells," Advances in Biological Regulation, vol. 9, no. 2, pp. 95-102, 2015.

[34] S. S. Dahham, "Antioxidant activities and anticancer screening of extracts from banana fruit (Musa sapientum)," Academic Journal of Cancer Research, vol. 8, pp. 28-34, 2015.
[35] Y. H. Cheah, H. L. P. Azimahtol, and N. R. Abdullah, "Xanthorrhizol exhibits antiproliferative activity on MCF-7 breast cancer cells via apoptosis induction," Anticancer Research, vol. 26, no. 6B, pp. 4527-4534, 2006.

[36] X.-M. Mao, P. Zhou, S.-Y. Li et al., "Diosgenin suppresses cholangiocarcinoma cells via inducing cell cycle arrest and mitochondria-mediated apoptosis," OncoTargets and Ther$a p y$, vol. 12, pp. 9093-9104, 2019.

[37] F. B. Machado, R. E. Yamamoto, K. Zanoli et al., "Evaluation of the antiproliferative activity of the leaves from Arctium lappa by a bioassay-guided fractionation," Molecules, vol. 17, no. 2, pp. 1852-1859, 2012.

[38] S. Foldeak and G. Dombradi, "Tumor-growth inhibiting substances of plant origin. I. Isolation of the active principle of Arctium lappa," Acta Physico-Chimica, vol. 10, pp. 91-93, 1964.

[39] C. Liu, K. D. Srivastava, N. Yang et al., "Arctigenin isolated from Arctium lappa L. Inhibits IgE production," Journal of Allergy and Clinical Immunology, vol. 137, no. 2, p. AB236, 2016.

[40] H. Ali, S. Dixit, S. Alqahtani, D. Ali, S. Alkahtani, and S. Alarifi, "Isolation and evaluation of anticancer efficacy of stigmasterol in a mouse model of DMBA-induced skin carcinoma," Drug Design, Development and Therapy, vol. 9, pp. 2793-2800, 2014.

[41] T. A. Woyengo, V. R. Ramprasath, and P. J. H. Jones, “Anticancer effects of phytosterols," European Journal of Clinical Nutrition, vol. 63, no. 7, pp. 813-820, 2009.

[42] C. Park, D.-O. Moon, C.-H. Rhu et al., " $\beta$-Sitosterol induces anti-proliferation and apoptosis in human leukemic U937 cells through activation of caspase- 3 and induction of bax/bcl2 ratio," Biological \& Pharmaceutical Bulletin, vol. 30, no. 7, pp. 1317-1323, 2007.

[43] S. Toné, K. Sugimoto, K. Tanda et al., "Three distinct stages of apoptotic nuclear condensation revealed by time-lapse imaging, biochemical and electron microscopy analysis of cellfree apoptosis," Experimental Cell Research, vol. 313, no. 16, pp. 3635-3644, 2007.

[44] C. F. Labuschagne, F. Zani, and K. H. Vousden, "Control of metabolism by p53 - cancer and beyond," Biochimica et Biophysica Acta (BBA)-Reviews on Cancer, vol. 1870, no. 1, pp. 32-42, 2018.

[45] D. F. Pierce, A. E. Gorska, A. Chytil et al., "Mammary tumor suppression by transforming growth factor beta 1 transgene expression," Proceedings of the National Academy of Sciences, vol. 92, no. 10, pp. 4254-4258, 1995.

[46] Y. Katsuno, S. Lamouille, and R. Derynck, "TGF- $\beta$ signaling and epithelial-mesenchymal transition in cancer progression," Current Opinion in Oncology, vol. 25, no. 1, pp. 76-84, 2013.

[47] A. B. Roberts and L. M. Wakefield, "The two faces of transforming growth factor in carcinogenesis," Proceedings of the National Academy of Sciences, vol. 100, no. 15, pp. 86218623, 2003.

[48] M. Barlett and T. Gilmore, "Control of apoptosis by Rel/NF$\kappa \mathrm{B}$ transcription factors," Oncogene, vol. 18, no. 49, pp. 6910-6924, 1999.

[49] F. Liu, K. Bardhan, D. Yang et al., "NF- $\kappa$ B directly regulates Fas transcription to modulate fas-mediated apoptosis and tumor suppression," Journal of Biological Chemistry, vol. 287, no. 30, pp. 25530-25540, 2012.

[50] L. A. Stark, F. V. N. Din, R. M. Zwacka, and M. G. Dunlop, "Aspirin-induced activation of the NF- $\kappa \mathrm{B}$ signaling pathway: a novel mechanism for aspirin-mediated apoptosis in colon 
cancer cells," The FASEB Journal, vol. 15, no. 7, pp. 1273-1275, 2001.

[51] J. F. R. Kerr, "History of the events leading to the formulation of the apoptosis concept," Toxicology, vol. 181-182, pp. 471474, 2002.

[52] J. A. Plumb, Cancer Cell Culture: Methods and Protocols, Humana Press, Totowa, NJ, USA, 2004.

[53] H. Yamaguchi, J. Wyckoff, and J. Condeelis, "Cell migration in tumors," Current Opinion in Cell Biology, vol. 17, no. 5, pp. 559-564, 2005.

[54] C. C. Mader, M. Oser, M. A. O. Magalhaes et al., "An EGFRsrc-arg-cortactin pathway mediates functional maturation of invadopodia and breast cancer cell invasion," Cancer Research, vol. 71, no. 5, pp. 1730-1741, 2011.

[55] J. Folkman, "Role of angiogenesis in tumor growth and metastasis," Seminars in Oncology, vol. 29, no. 6, pp. 15-18, 2002.

[56] A. Ahluwalia and A. S. Tarnawski, "Critical role of hypoxia sensor - HIF-1 $\alpha$ in VEGF gene activation. Implications for angiogenesis and tissue injury healing," Current Medicinal Chemistry, vol. 19, no. 1, pp. 90-97, 2012.

[57] K. Kovacs, K. V. Marra, G. Yu et al., "Angiogenic and inflammatory vitreous biomarkers associated with increasing levels of retinal ischemia," Investigative Opthalmology \& Visual Science, vol. 56, no. 11, pp. 6523-6530, 2015.

[58] A. H. Yehya, "Broad spectrum targeting of tumor vasculature by medicinal plants: an updated review," Journal of Herbal Medicine, vol. 9, pp. 1-13, 2017. 